\title{
Lung Development in the Fetal Primate Macaca Nemestrina. III. HMD
}

\author{
JOHN L. PRUEITT, SUSAN PALMER, THOMAS A. STANDAERT, DANIEL L. LUCHTEL, JANET H. \\ MURPHY, AND W. ALAN HODSON \\ Departments of Pediatrics and Environmental Health, University of Washington, Seattle, Washington
}

\begin{abstract}
Summary
Delivery of $M$. nemestrina at $80 \%$ of normal gestation provides a population of neonates at high risk for hyaline membrane disease (HMD). The diagnosis of HMD was made by the presence of reticulogranular densities and air bronchograms on chest radiographs. Patchy atelectasis was seen in the lungs of animals assigned by clinical and radiographic criteria to the HMD group and not in the normal lungs of animals matched for gestational and postnatal age. Total phospholipid and phosphatidylcholine in whole lung, airway lavage fluid, and surface-active materials were lower in animals with HMD. Amniotic fluid $L / S$ ratios were lower in the group that developed HMD. Pressure-volume measurements indicated decreased distensibility and unstable terminal air spaces in the HMD group. Alveolar-arterial oxygen pressure differences
\end{abstract}

were greater in animals with HMD. There were no differences between HMD and normal groups in body weight, lung weight, percent dry lung weight, gestational age, and postnatal age at death. This primate species, subjected to premature delivery, is a suitable animal model of HMD in human neonates.

\section{Speculation}

An animal model of hyaline membrane disease (HMD) in a primate species is of interest to investigators of developmentally related pulmonary disorders. More complete knowledge of abnormalities in pulmonary function in HMD will contribute to development of both preventive and therapeutic measures and affords the opportunity to determine risks and benefits of such treatments to the fetus and newborn. 


\section{Introduction}

Hyaline membrane disease (HMD) is the major cause of neonatal mortality in the United States (10). Rational prevention and therapy of HMD may be derived from more complete knowledge of abnormalitles in pulmonary function that occur In this dsorder. Derlnition of altered pulmonary mechanics, surfactant, and structure, particularly the sequential changes during onset and subsequent re allows control of variables that affect these measurements. Evaluation of allows control of variables that affect these measurements. Evaluation of risk is also an advantage afforded by the study of HMD ine maternal and fetal propose that the primate Macaca nemestrina is a suitable model for HND when elivered prematurely.

Development of the model for HMD followed studies of lung development in fetal $\mathrm{M}$. nemestrina from 108 to 168 (term) days gestation (15,22). After 130 days phosphollpid (PL) and phosphatidylcholine (PC) in whole lung and surface increase in increase in total Iung volume and alveolar stablilty. After 150 days pressurevolume relationships were similar to those described at term (22). We reasone ment, between 130 and 145 days, would provide a population of neonates at high risk for FMD that would be sufficiently mature to survive ex utero. The production of the model and description of abnormalities in chest radiographs, gas exchange, pressure-volume measurements, structure, and PL in lung, SAM, and amniotic fluid are the subjects of this report. Preliminary results of these studies have been reported in abstract $(20)$.

\section{Materials and Methods}

Pregnant $M$. nemestrina were obtalned from the University of Washington Regional Primate Center Field Station, Medical Lake, Washington. Duration of gestation was known within one day as a result of matings of Individualiy caged females. Pregnancies were terminated by cesarean section as previously described (15). Samples of amnlotic fluid were obtained by needle asplration of the amiotic cavity prior to uterine inclsion. At delivery the animals were the amiotic cavity prior to uterine incision. At dellvery the animals were
placed under a radiant heater and dried thoroughly with towels. The oropharynx placed under a radiant heater and dried thoroughly with towels. The oropharyna
was cleared of fluid by bulb syringe. When the animals did not breathe spontaneously, intermittent positive pressure with oxygen was administered with an anesthesia bag and endotracheal tube until spontaneous ventilation was present. A $3.5 \mathrm{Fr}$. ga. catheter was inserted through an umbilical artery and into the aorta. The tip of the catheter was positioned at a level between the sixth and eighth thoracic vertebrae. A tracheostomy was performed using a modified blunt hourly to maintain a patent alrway. Chest radiographs were obtained within hourly to maintain a patent alrway. Chest radiographs were obtained within one tions and to evaluate the lung flelds. They were repeated between four and six hours of age.

Animals were maintained in incubators during the experiments. The environmental temperature was adjusted in an attempt to maintain core temperatures of $37^{\circ} \mathrm{C}$. Dextrose $(5 \%)$ in water was infused through the arterial catheter (Holter Pump No. 903 , Extracorporeal Medical Specialties, King of Prussia, PA) at a cona flow rate approximately 5 times the minute ventilation. Fractional inspired oxygen concentration ( $\mathrm{F}_{2} \mathrm{O}_{2}$ ) was adjusted to maintain $\mathrm{PaO}_{2} 50-80 \mathrm{~mm} \mathrm{Hg}$. Animals who developed persistent apnea or hypercarbla $\left(\mathrm{PaCO}_{2}>7 \mathrm{fm} \mathrm{Hg}\right)$ were mechanically ventilated with a respiration pump (Harvard Apparatus, Mililis, MA). Carbon dioxide tension in arterial blood was maintained in the range $30-45 \mathrm{~mm}$ Hg in mechanically ventilated animals. Arterial blood gas tensions and pH were measured hourly or 15 minutes after a change in $\mathrm{F}_{\mathrm{O}} \mathrm{O}$ or ventilator settings ( $\mathrm{pH} /$ Blood Gas Analyzer 713, Instrumentation Laboratories, Lexington, MA). Heparinized placental blood obtained at delivery from the umbllical cord was used to replace sample volumes. Alveolar-arterial oxygen tension differences were cal-
culated from a modification of the alveolar air equation and blood gas tensions measured after the anfmals breathed oxygen for at least 20 minutes.

Animals were sacrificed between 6 and 8 hours of age by injection of pentobarbital, $150 \mathrm{mg} / \mathrm{kg}$, through the aortic catheter. The lungs were removed immescopic studies as described below. Samples of the remalnder of the right lung were excised and weighed for dry weight determinations and homogenization (15):
The left lung was weighed and pressure-volume measurements were performed (22): The lung was degassed in a vacuum bell-jar using $15 \mathrm{~cm} \mathrm{H}_{2} \mathrm{O}$ negative pressure and alrlessness determined by visual inspection. All lungs were distended with a maximum pressure of $35 \mathrm{~cm} \mathrm{H} \mathrm{O}^{\mathrm{O}}$ to ensure maximum inflation without causing lung rupture. Lung volume was calculated by dividing the maximum volume of the left lung by the wet weight of the left lung. The left lung was then lavaged with $3 \mathrm{ml}$ of homogenization medium. The fluid was gently withdrawn with a syringe. The procedure was performed five times in each lung. The fluid was centrifuged
at $150 \times \mathrm{g}$ for 5 minutes to remove cells and debris, and the supernatant was exat $150 \times g$ for 5 minutes to remove cell
tracted for lipids as described below.

The methods used to 1solate SAM, extract and purify lipids, measure lipid phosphorus, separate phospholipids, and calculate lecithin/sphingomyelin (L/S) ratios have been previously described (22). Disaturated phosphatidylcholines (DPC) were measured by the method of Mason et al (19). An internal standard of dipalmitoyl-1-14 C phosphatidylcholine (Applied Sclence Laboratories, Inc., State * (mean $\pm 1 S D$ ), $n=24$. Ninety-nine percent of fatty acids recovered in disaturated fractions were saturated, and palmitic ac1d was $92 \%$ of total saturated fatty acids.

The right upper lobe was studied by light and electron microscopy. Glutar-

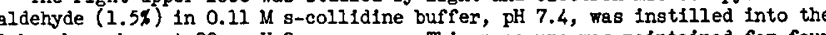
lobar bronchus at $20 \mathrm{~cm} \mathrm{H}_{2} \mathrm{O}$ pressure. This pressure was maintained for four hours while the lobe was suspended in a bath of fixative. The lobe was stored
overnight in glutaraldehyde at $4^{\circ} \mathrm{C}$ and was then sliced with razor blades (1-2 ming thick slices) The glices were rinsed in $0.11 \mathrm{M} \mathrm{s}$-collidine, post-fixed In uranyl acetate. The tissue was dehydrated in ethanol and emoedded in t.pos 812. uranyl acetate. The tissue was dehydrated in ethanol and embedded in kpon 812 . Ome $\mu$ m sections were cut with steel knives, and further sampling procedures thin sectioning were done according to the methods of Boatman and Lowe ( 3 ). Thin sections were stained with uranyl acetate and lesd citrate and examined without knowledge of the clinical and radiographic evaluations and results of other analyses.

Animals were grouped for data analysis on the basis of clinical evidence of chest wall retractions and tachypnea and chest radiographs. The diagnosis of HMD was made by the presence of retlculogranular densitles and an air bronchogram on chest radiographs. Radiographs were evaluated by seven examiners independently and without knowledge of the clinical conditions of the animals and of $\mathrm{HMD}$ or normal was made by at least 4 of the 7 examfners the animal was as- signed to the HMD or normal groups, respectively. When asalgnment on that basis was not possible those animals were not included in the analyses.

Differences between means were tested for significance by student's t test. Results

Eleven monkeys were delivered by cesarean section between 135 and 142 days gestation. A diagnosis of HMD was made in five animals; three animals were normal; and in three animals a diagnosis could not be made by the stated criterla. The five anfmals with HMD had clinical evidence of respiratory distress with chest wall retractions and tachypnea; cyanosia was present in amblent atmos-
phere. Four of $f$ ive animals in the HMD group were vent1lated mechanically because vent1latory failure and/or apnea occurred between the second and fourth hours of the experiments. The peak $\mathrm{F}_{\mathrm{T}} \mathrm{O}$ requirement was 1.0 in all $\mathrm{HMD}$ animals. The three normal animals breathed spontinneously during the entire course of the experiments. Two normal animals recelved oxygen in low concentration ( $\mathrm{F}_{\mathrm{T}} \mathrm{O}_{2} 0.2$ - 0.40). The third normal animal had satisfactory $\mathrm{PaO}_{2}$ in alr for the efitfre dures, and core temperatures were maintained in the range $35-38^{\circ} \mathrm{C}$

Chest radiographs of HMD and normal animals of the same gestational and postnatal age are shown in Figure 1.

The normal and HMD groups are compared in Table 1. Both groups were simflar in gestational age and postnatal age at death. There were no differences between the groups in body weight, lung weight, and percent dry lung welght. Al-

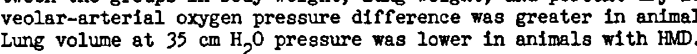

The results of pressure-volume measurements during deflation are shown in Figure 2. The percentage of maximum lung volume retalned at $15,10,5$, and 2.5 $\mathrm{cm} \mathrm{H} \mathrm{O}^{\mathrm{O}}$ pressure was lower in the HMD group. The large variance in the HND group the total lung volume was retained at $\mathrm{O} \mathrm{cm} \mathrm{H}_{2} \mathrm{O}$ pressure.

The results of phospholipid measurements are shown in Tabie 2. Total PL and a were lower in animals with HMD. Total DPC In lung was lower in the HMD group. Determinations of DPC in SAM were made in only one normal and two HMD animals, and statistical comparison is not possible. The finding of an approximately five-fold greater amount in the normal animal suggests that the recovery of SAM DPC 18 also lower in HMD. AM-
niotic fluid L/S ratios were lower in the group of animals that developed HMD.

The results of microscopic examinations were consistent with the radiogrsphic diagnoses (Figures 3 and 4 ). Patchy atelectasis, characteristic of $\mathrm{HMD}$ (16), was seen in the lungs of animals in the FMD group and not in the normal lungs. The extent of the atelectasis varied from animal to animal within the to group. The walls of the alrspaces were thicker in the HMD group compared to normals (Figures 38 and $4 \mathrm{a}$ ). Extensive damage to the epithellal cells the presence of necrotic cells in the airspaces (Figures 30 and $4 \mathrm{~b}$ ), was seen in $\mathrm{HMD}$ animals.

\section{Discussion}

These experiments indicate that $M$. nemestrina fetuses delivered by cesarean section at about $80 \%$ of term gestation may manifest respiratory distress and radiographic slgns of $\mathrm{HMD}$. This primate species, subjected to premature birth, suitable animal model of HMD in human neonates.

The assignment to HMD and normal groups was made in 45 percent and 27 percent, respectively, of the anfmals delivered between 135 and 142 days gestation. In the remaining 27 percent of animals a definite assignment to one or the other groups could not be made by the stated criterla. Selection of this ges tational age range for premature dellvery provided the opportunity to study
both normal and $\mathrm{HMD}$ animals. Differences in SAM measurements and pressure-volune relationships between the two groups probably reflect variations in rates of lung maturation that influence the Incidence of $M M D$.

Animals with HMD had lower anniotic fluid L/S ratios, alrway PL, and homogenate SAM PL compared to normals. Also, total lung volume and the percentage. of total lung volume retalned at low almway pressure was lower in the HND group, indicating decreased distensibility and unstable terminal air spaces, respectively. These findings indicate a deficlency in effectlve surfactant and are consistent with data from studies of human lungs that indicate that surfactan Is deficient in HMD $(1,4,14)$. Also consistent with human data is the finding developed clinical and radiographic signs of $\mathrm{kMD}(5,11,24)$.

These investigations do not delineate the mechaniam of reduced SAM recovery and abnormal pressure-volume relationships measured at six to elght hours postnatal age. However, the finding of lower amiotic fluid L/S ratios in HMD suggests that deficiency of surfactant at delivery is the major factor in the genesis of HMD in $M$. nemestrina. Other factors such as insufficient surfactan transudation of plasma proteins into air spaces $(6,26)$ may contribute to protransudation of plasma proteins into air spaces (6,26) may contribute to proset. Studies of synthesis and secretion of SAM, detalled analyses of SAM comset. Studies of synthesis and secretion of SAM, detailed analyses of SAM composition in both health and disease, and careful surface tension measuremento assess the roles of these factors.

The clinical diagnosis of HMD was substantlated by histological and ultrastructural examination of the lung tissue. Patchy atelectasis, increased thickness of the saccular septa, and epithelial cell necrosis were characteris tic of the HMD animals. The extent of atelectasis may have been diminished by
the fixation procedure (airway instillation of fixative at $20 \mathrm{~cm} \mathrm{H}_{2} \mathrm{O}$ pressure). the fixation procedure (airway instillation of flxative at $20 \mathrm{~cm} \mathrm{H}_{2} \mathrm{O}$ pressure). The increased thicimess of the saccular walls may be due to a number of factor
interstitial edema formation, intracellular edema and cellular necrosis, and interstitial edema formation, Intracellular edema and cellular necrosis, and inflammatory response (cellular infiltration). Fndothelial cell swelling and
capillary occlusion was noted in both the normal and $\mathrm{HM}$ animals. Part of the capillary of the vasculature may be attributable to the method of fixation; that 18, much of the blood may have drained from the vasculature during dissection 18, much of the blood may have drained from the vasculature during dissection lar debris in the a
of the HMD animals.

Ventilation was assisted in four of five IMD animals and has been reported to Increase PL recovered in alrways lavage (21). However, this effect of ventilation is much too small to account for the differences described here in PL
in whole lung and SAM between normal and HMD lungs. The value for alrway PL in whole lung and SAM between normal and HMD lungs. The value for alrway PL of $2.2 \mathrm{~g} / \mathrm{g}$ dry lung in the non-ventilated animal compared to the group mean of
$2.2 \pm 0.7$ (SD) and lower alrway PL in the HMD group compared to the normal group 
indicates that assisted ventilation was not responsible for the difference between groups.

This homologue of HMD should be of interest to investigators of developmentally related pulmonary disorders. The model provides opportunity to measure gas exchange, lung mechanics, structure, and surfactant metabolism in order to define Initlal abnornalities and subsequent changes that occur during the cours pr in. The mode or actlon or therapeutio techniques such as positive alrway pressure $(2,8,13,23)$ may also be assessed. Ihis model ls also sultable for the study or pharmacologlc acceleration of maturation of the fetal lung $(7,17,18$, or prevtion and trestment of $\mathrm{MMD}$.

\section{REFERENCES}

1. Avery, M.E., and Mead, J.: Surface properties in relation to atelectasis and hyaline membrane disease. Amer. J. Dis. Child. 97:517 (1959)

2. Belenky, D.A., Orr, R.J., Woodrum, D.E., and Hodson, W.A.: Is continuous transpulmonary pressure better than conventional respiratory management of hyaline membrane disesse? A controlled study. Pediatrics, 58: 800 (1976).

3. Boatman, E.S., and Lowe, D.: Photographic mapping of a tissue surface to locate fields for electron microscopy: mouse lung. Stain Tech. 46: 63 (1971).

4. Brumley, G.W., Hodson, W.A., and Avery, M.E.: Lung phospholipids and surface tension correlations in infants with and without hyaline membrane disease and in adults. Pediatrics, 40:13 (1967).

5. Bryson, M.J., Gabert, H.A., and Stenchever, M.A.: Amfotic fluid lecithin/ sphingomyelin ratio as an assessment of fetal pulmonary maturity. Amer. J. Obstet. Gynecol., 114:208 (1972).

6. Chu, J., Clements, J.A., Cotton, E., Klaus, M.H., Sweet, A.Y., Thomas, M.A., and Tooley, W.H.: The pulmonary hypoperfusion syndrome. Pediatrics, 35: 733 (1965).

7. Dluholucky, S., Bable J., and Taufer, I.: Reduction of incidence and mor= tality of respiratory distress syndrome by administration of hydrocortisone to mother. Arch. Dis. Child., 51: 420 (1976).

8. Durbin, G.M., Hunter, N.J., McIntosh, N., Reynolds, E.O.R., and Wimberley, P.D.: Controlled trial of continuous inflating preasure for hyaline membrane disease. Arch. Dis. Ch1ld., 51: 163 (1976).

9. Farrell, P.M., and Avery, M.E.: Hyaline membrane disease. Amer. Rev. Resp. Dis., 111: 657 (1975).

10. Farrell, P.M., and Wood, R.E.: Epldemiology of hyaline membrane disease in the United States: Analysis of national mortality statistics. Pediatrics, 58: 167 (1976).

11. Gluck, L., Kulovich, M., Borer, R., Brenner, P.H., Anderson, G.G., and Spellacy, W.N.: Diagnosis of the respiratory distress syndrome by am niocentes1s. Amer. J. Obstet. Gynecol., 109:440 (1971).

12. Gluck, L., Kulovich, M., Eidelman, A.I., Cordero, L., and Khazin,A.F.:
Biochemical development of surface activity in mammalian lung. IV. Pulmonary lecithin synthesis in the human fetus and newborn and etiology of the respiratory distress syndrome. Pedist. Res., 6:81 (1972).

13. Gregory, G.A., Kitterman, J.A.; Phibbs, R.H., Tooley, W.H., and Hamilton, W.K.: Tratment of the 1diopathic respiratory distress syndrome. w1 th continuous positive airway pressure. N. Engl. J. Med., 284: 1333 (1971)

14. Gribetz, I., Frank, N.R., and Avery, M.E.: Static volume-pressure relat1ons of exclsed lungs of infants with hyaline membrane disease, newborn and stillborn infants. J. Clin. Invest., 38: 2168 (1959).

15. Hodson, W.A., Palmer, S., Blakely, G.A., Murphy, J.H., Woodrum, D.E., and Morgan, T.E.: Lung development in the fetal primate, Macaca nemestrina.
I. Growth and compositional changes. Pediat. Res., 11: $1051 \frac{1}{(1977)}$.

16. Lauweryns, J.M.: Hyaline membrane disease: A pathological study of 55 infants. Arch. Dis. Child., 40:618 (1965).

17. Liggins, G.C., and Howie, R.N.: A controlled trial of antepartum glucocorticoid treatment for prevention of the resplratory distress syndrome in premature infants. Pediatrics, 50: 515 (1972).

18. Liggins, G.C., and Howle, R.N.: The prevention of RDS by maternal sterold therapy. In: I. Gluck: Modern Perinatal Medicine, pp. 415-424 (Year Book Medical Publishers, Chicago, 1974).

19. Mason, R.J., Nellenbogen, J., and Clements, J.A.: Isolation of disaturated phosphatidylcholine with osmium textroxide. J. Lipld Res., 17: 281
(1976).

20. Murphy, J., Palmer, S., Prueltt, J., Yount, J., Standaert, T., Morgan, T., and Hodson, w.: Hyaline membrane disease in the premature monkey. Amer. Rev. Resp. Dis., 113: 44 Suppl. (1976).

21. Oyarzain, M.J., and Clements, J.A.: Ventilatory and cholinergic control of
pulmonary surfactant in the rabbit. J. Appl. Physiol., 43(1): 39 (1977)

22. Palmer, S., Morgan, T.E., Prueitt, J.L., Murphy, J.H., and Hodson, W.A.: Lung development in the fetal primate, Macace nemestrina. II. Pressure-
volume and phospholfpid changes. Pediat. Res., 11: $105^{7}$ (1977).

23. Rhodes,P.G., and Hall, R.T.: Continuous positive afrway pressure delivered by face mask in infants with the 1diopathic respiratory distress syndrome: A controlled study. Pediatrics, 52: 1 (1973).

24. Schulman, J.D., Queenan, J.T., Scarpell1, E.M., Church, E., and Auld, P.A. M.: Lec1 thin-sphingomyelin ratios in amiotic fluid. J. Obstet. Gynecol., 40: 697 (1972).

25. Taeusch, H.W.: Glucocorticoid prophylaxis for respiratory distress syn-
drome: A review of potent1al toxic1ty. J. Pediatr., 87: 617 (1975).

26. Taylor, F.B., and Abrams, M.E.: Effect of surface active 11poprotein on clotting and fibrinolysis, and of fibrinogen on surface tension of surface active 11poprotein. Amer. J. Med., 40: 346 (1966).

27. Received for publication, May 15, 1978.

28. Accepted for publication, February 1, 1979.

Table 1. Individual and mean values in normal and fMD animals.

\begin{tabular}{|c|c|c|c|c|c|c|c|}
\hline & $\begin{array}{c}\text { Gestational age } \\
\text { (days) }\end{array}$ & $\begin{array}{c}\text { Postnatal age } \\
\text { (hours) }\end{array}$ & $\begin{array}{c}\text { Body Wt. } \\
(g)\end{array}$ & $\begin{array}{l}\text { Lung Wt. } \\
\text { (g) }\end{array}$ & $\begin{array}{l}\text { Lung Wt. } \\
\text { ( } \% \text { dry) }\end{array}$ & $\begin{array}{l}\mathrm{P}(\mathrm{A}-\mathrm{a}) \mathrm{O}_{2} \\
(\mathrm{~mm} \mathrm{Hg})\end{array}$ & $\begin{array}{r}\text { Lung Vo] } \\
(\mathrm{cc} / \mathrm{g})\end{array}$ \\
\hline \multirow[t]{3}{*}{ Normal } & 137 & 6.0 & 379 & 5.31 & 14.2 & 497 & 2.9 \\
\hline & 137 & 6.9 & 320 & 4.85 & 13.2 & 357 & 3.3 \\
\hline & 142 & 8.0 & 414 & 6.39 & 13.2 & & 2.3 \\
\hline mean & 139 & 7.0 & 368 & 5.52 & 13.5 & 427 & 2.8 \\
\hline SD & 3 & 1.0 & 47 & 0.79 & 0.6 & 99 & 0.5 \\
\hline \multirow[t]{5}{*}{ HMD } & 135 & 6.9 & 257 & 5.44 & 14.0 & 637 & 1.2 \\
\hline & 136 & 6.9 & 340 & 4.90 & 15.2 & 595 & 1.4 \\
\hline & 136 & 6.7 & 349 & 6.53 & 11.6 & 597 & \\
\hline & 137 & 6.3 & 315 & 5.59 & 25.9 & 611 & 1.3 \\
\hline & 139 & 6.4 & 372 & 6.28 & 12.8 & 611 & 1.0 \\
\hline mean & 137 & 6.6 & 327 & 5.75 & 13.9 & 610 & 1.2 \\
\hline SD & 2 & 0.3 & 44 & 0.66 & 1.8 & 17 & 0.2 \\
\hline$P$ & NS & NS & NS & NS & NS & $<0.01$ & $<0.005$ \\
\hline
\end{tabular}


Table 2. Individual and mean phospholipid measurements in normal and HMD animals. 1

\begin{tabular}{|c|c|c|c|c|c|c|c|c|c|}
\hline & \multicolumn{3}{|c|}{ Whole lung } & \multicolumn{2}{|c|}{ Afrways lavage } & \multicolumn{3}{|c|}{ SAM } & \multirow{2}{*}{$\begin{array}{l}A F \\
L / S\end{array}$} \\
\hline & PL & $\mathrm{PC}$ & DPC & PL & PC & PL & $\mathrm{PC}$ & DPC & \\
\hline \multirow[t]{3}{*}{ Normal } & $108.6^{2}$ & 56.7 & 28.7 & 25.0 & 19.8 & 27.8 & 22.3 & 10.8 & 3.8 \\
\hline & 108.0 & 55.1 & 25.4 & 19.4 & 15.8 & 25.8 & 21.7 & & 3.6 \\
\hline & 90.9 & 48.5 & 21.8 & 9.9 & & 12.7 & & & \\
\hline Mean & 102.5 & 53.4 & 25.3 & 18.1 & 17.8 & 22.1 & 22.0 & & 3.7 \\
\hline SD & 10.0 & 4.4 & 3.4 & 7.6 & 2.8 & 8.2 & 0.4 & & 0.1 \\
\hline \multirow[t]{5}{*}{ HMD } & 76.8 & 32.6 & 10.7 & 3.2 & & 4.7 & & 1.4 & 1.2 \\
\hline & 73.5 & 32.7 & 12.9 & 1.9 & 1.0 & 8.7 & 4.5 & 2.4 & 1.5 \\
\hline & 91.5 & 37.4 & 14.5 & & & 5.9 & & & 1.5 \\
\hline & 75.0 & 34.0 & 12.6 & 1.6 & 1.1 & 3.8 & 2.6 & & 1.0 \\
\hline & 82.5 & 34.5 & 13.5 & 2.2 & & 6.3 & 3.5 & & \\
\hline $\bar{X}$ & 79.8 & 34.3 & 12.8 & 2.2 & 1.1 & 5.9 & 3.5 & 1.9 & 1.3 \\
\hline SD & 7.4 & 2.0 & 1.4 & 0.7 & 0.1 & 1.9 & 0.9 & 0.7 & 0.3 \\
\hline $\mathbf{P}$ & $<0.01$ & $<0.001$ & $<0.001$ & $<0.01$ & $<0.025$ & $<0.005$ & $<0.001$ & & 0.001 \\
\hline
\end{tabular}

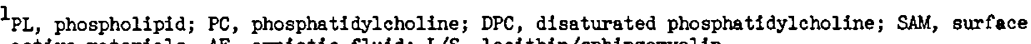
active materials, AF, amniotic fluid; L/S, lecithin/sphingomyelin.

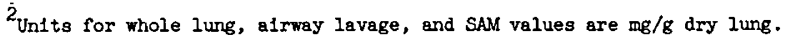
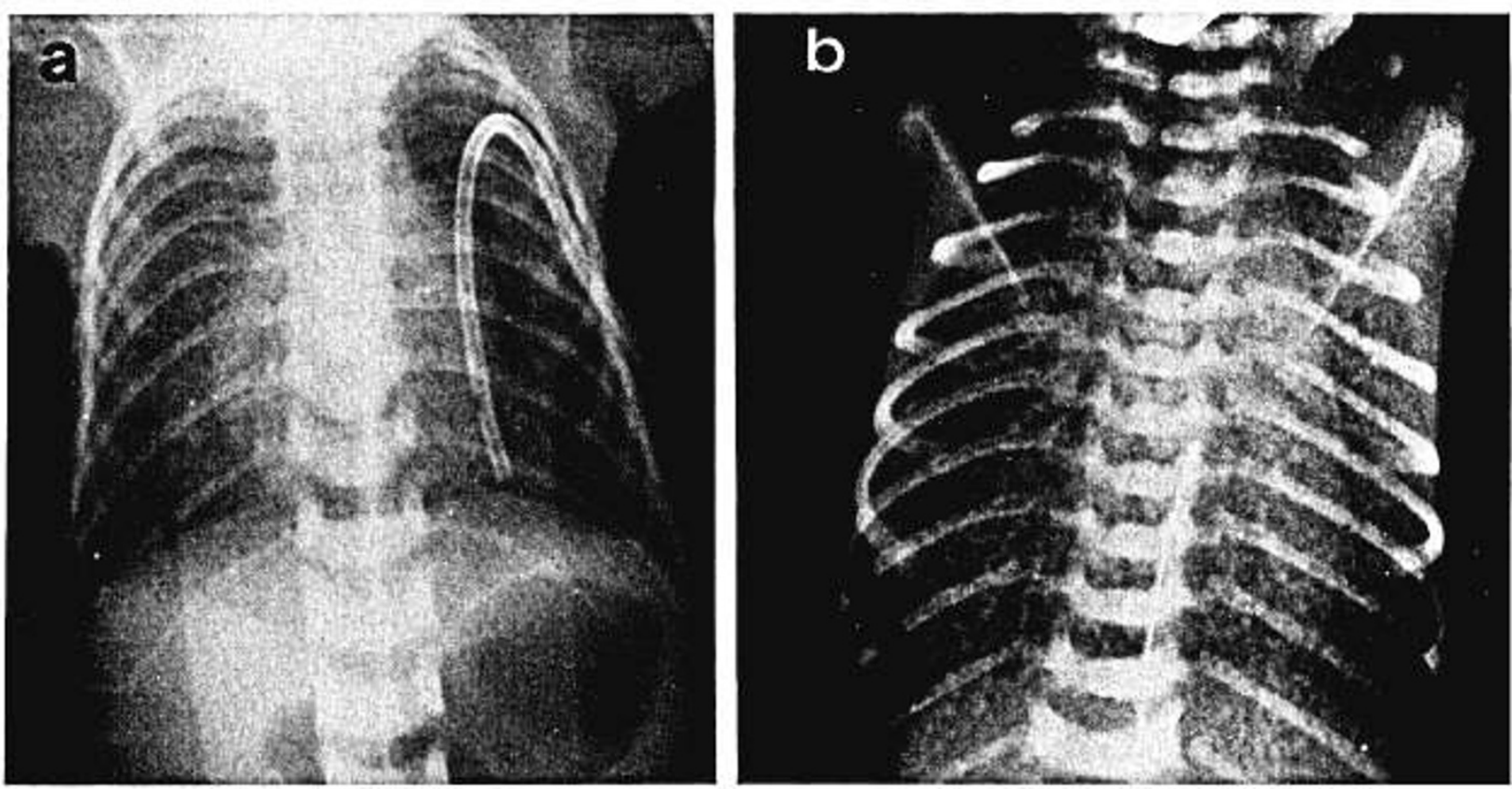

Figure 1. - Chest radiographs of $M$. nemestrina. (a) Normal. The catheter in the pleural space was used to measure pleural pressure in other studies. (b) Hyaline membrane disease. Gestational age was 137 days in both animals. Body welghts were (a) $320 \mathrm{~g}$ and (b) $315 \mathrm{~g}$. 


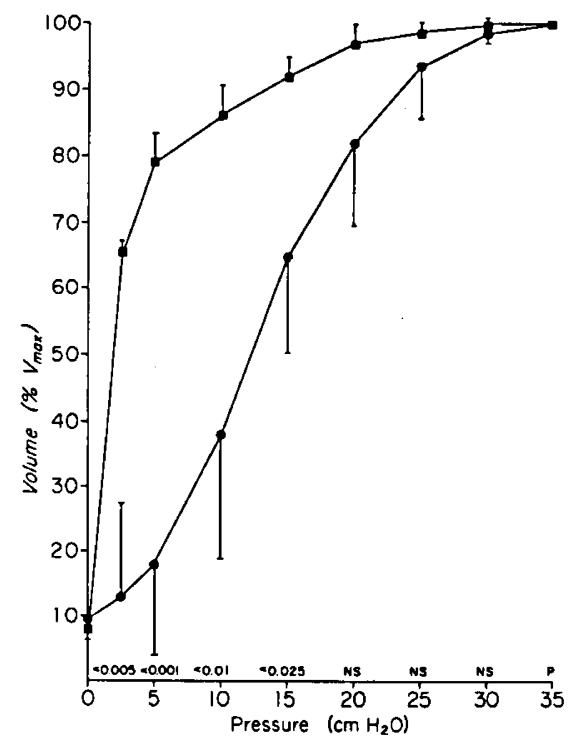

Fipure 2. - Pressure-volume measurements during deflation. The upper curve (i) represents 3 normal animals. The lower curve (-) represents 5 ani-

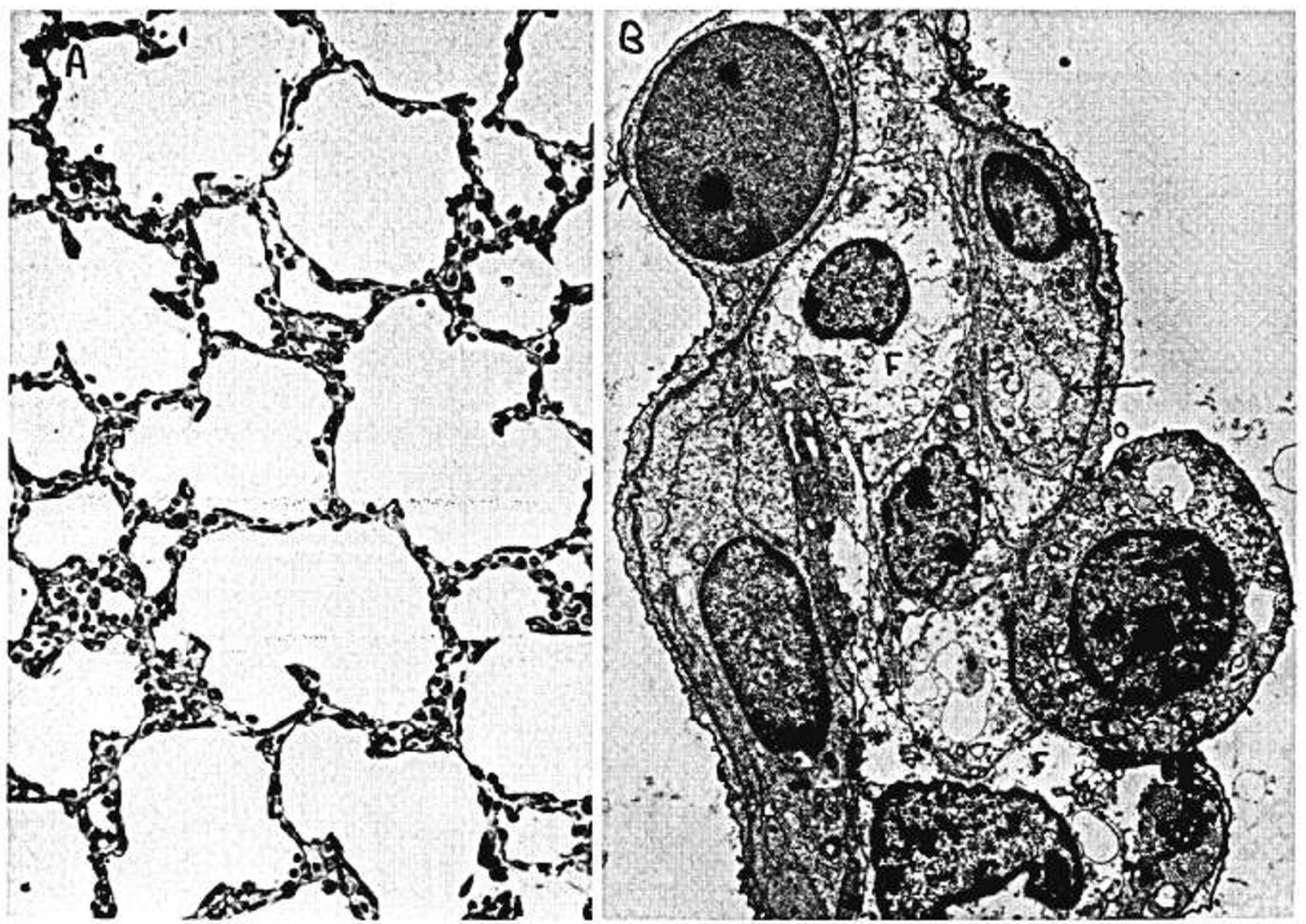

Figure 3 - The typical appearance of lung tissue in a normal animal. Gestational age was 137 days. (a) Light microscopic appearance of the parenchyma. The saccules are well expanded and have relatively thin walls. 150x. (b) An electron micrograph of a saccular septum. It is lined by thin type I epithella cells; a cuboidal type II cell is also shown on the right side of the septum. In the interstitium, fibroblasts $(F)$ show intracellular edema and the endothe11al cells lining the capillaries are swollen. The lumens of capillarles tend to be collapsed and/or occluded (arrows). 3600x. 


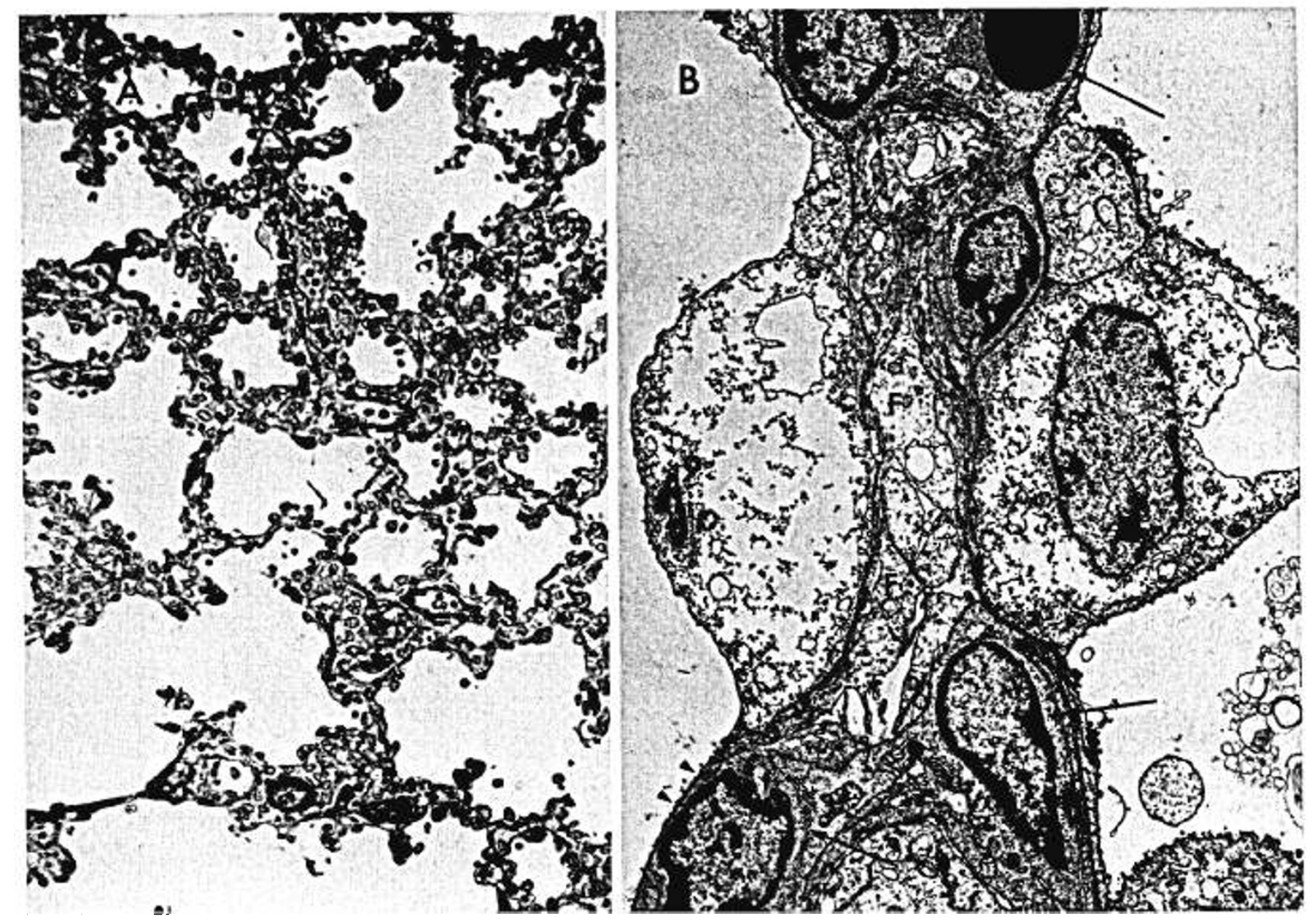

Figure 4. - The typical appearance of lung tissue in a HMD animal. Gesta-

tional age was 137 days. (Light mfcroscopic appearance of an expanded, non-

atelectatic region of the parenchyma. The saccular walls are increased in

thickness compared to the normal group. 150x. (b) An electron micrograph

one of the thinner saccular septa, as shom in (a). Eplthellal cells are

swollen and, in some cases, detached, leaving an exposed basement membrane

The endothelial cells are also swollen and the capillary lumens are collapsed

and/or occluded (arrows). $3600 x$.

Copyright $\odot 1979$ International Pediatric Research Foundation, Inc.

Printed in U.S.A. $0031-3998 / 79 / 1305-0654 \$ 02.00 / 0$ 